Endocrinol. Japon. 1990, 37 (2), 205-211

\title{
In Vivo Regulation of Hepatic Insulin-Like Growth Factor-1 Messenger Ribonucleic Acids with Thyroid Hormone
}

\author{
Seijiro HARAKAWA, Shunichi YAMAShitA, Tamami TOBINAGA, \\ KeIICHI MATSUO, HIDESHI HIRAYU, MOTOMORI IZUMI, \\ Shigenobu NAGATAKI and Shlomo MELMED*
}

\author{
The First Department of Internal Medicine, Nagasaki University School of \\ Medicine, Nagasaki 852, Japan \\ Division of Endocrinology, Cedars-Sinai Medical Center, UCLA, \\ Los Angeles 90048 USA*
}

\begin{abstract}
Insulin-like growth factor-1 (IGF-1) is synthesized primarily by the liver in response to growth hormone (GH). Thyroid hormone plays a major role in mediating pituitary GH secretion. In order to clarify the effect of thyroid hormone on IGF-1 gene expression, we measured hepatic IGF-1 mRNA levels in rats with thyroid dysfunction. Female Wistar rats were rendered hypothyroid by surgical thyroidectomy or hyperthyroid by daily injections of thyroxine $(12 \mu \mathrm{g} /$ day) for 2 weeks. Northern gel analysis of hepatic poly (A) RNA revealed the multiple sizes of the RNA transcripts ranging from 1.6 to $9.0 \mathrm{~kb}$. After 4 weeks, hepatic IGF-1 mRNA levels were suppressed in hypothyroid rats, to $<20 \%$ of control euthyroid animals. These suppressed mRNA levels were restored to euthyroid levels by thyroid hormone replacement for 2 weeks. Hyperthyroid rats, however, did not contain altered levels of hepatic IGF-1 mRNA as compared to euthyroid rats. The $\gamma$-actin mRNA hybridization signal was not altered in hypothyroid or hyperthyroid rats.

These results suggest that thyroid hormone regulates the in vivo expression of hepatic IGF-1 mRNA, probably through the mechanism of GH regulation.
\end{abstract}

It is well known that insulin-like growth factor-1 (IGF-1) mediates many of the growth-promoting actions of $\mathrm{GH}$ (Froesch et al., 1985). The source of circulating IGF-1 has been traditionally believed to be primarily hepatic (Van Wyk., 1985). In the rat, concentrations of immunore-

Received October 3, 1989

Correspondence : SHIGENOBU NAGATAKI; The First Department of Internal Medicine Nagasaki University school of Medicine, 7-1 Sakamoto-machi, Nagasaki 852, Japan. active IGF-1 in a number of tissues are reduced by hypophysectomy and restored to normal by $\mathrm{GH}$ replacement (D'Ercole et al., 1984). GH itself stimulates IGF-1 biosynthesis in the perfused rat liver (Schwander et al., 1983). In contrast, serum levels of GH and IGF-1 are very low in thyroidectomized rats (Yaffe and Samuels., 1984) and thyroid hormone itself stimulates GH gene expression in rat pituitary cells (Dobner et al., 1981). Furthermore, thyroid hormone directly regulates IGF-1 gene 
expression in GH3 rat pituitary cells (Fagin et al., 1987; Yamashita et al., 1989). These observations suggest the presence of an interaction between thyroid hormone and IGF-1 at the gene level.

In the present study, therefore, we have investigated the effects of thyroidectomy and thyroid hormone replacement on IGF1 mRNA levels in rat liver to establish whether previously observed effects of thyroid hormone status on serum and tissue IGF-1 concentrations are mediated at the level of hepatic IGF-1 mRNA abundance.

\section{Materials and Methods}

\section{Animals}

Female Wistar rats (Shizuoka Animal Center, Shizuoka, Japan), aged 3 months and weighing $220 \mathrm{~g}$, were surgically thyroidectomized or sham operated under pentobarbital anesthesia $(0.05$ $\mathrm{mg} / \mathrm{gBW}$ ) and maintained for 4 weeks. During this period, failure to gain weight confirmed the hypothyroid state of the thyroidectomized group. Thyroidectomized rats (group I) were sacrificed by decapitation and their livers aseptically removed, quickly frozen and stored at $-70^{\circ} \mathrm{C}$ for RNA extraction. Trunk blood was simultaneously collected for hormone RIA. Thyroidectomized rats (group 2) were injected daily with thyroxine $(12 \mu \mathrm{g} /$ day $)$ for five days and sacrificed by decapitation. A third group of rats (normal control rats) was injected daily with $\mathrm{T}_{4}(12 \mu \mathrm{g} /$ day) for two weeks and then sacrificed. Shamoperated control rats were similarly subjected to hepatic RNA extraction and blood sampling at identical times of sacrifice. Serum $T_{3}$ and $T_{4}$ were measured by radioimmunoassay (Eiken Chemical Co., Ltd. Tokyo, Japan).

\section{RNA extraction}

Hepatic RNA was extracted by acid-guanidinium thiocyanate and phenol-chloroform (Chomczynski and Sacchi, 1987) and poly (A) RNA was isolated with poly (U) messenger affinity paper (Werner et al., 1984). The UV absorbance was measured at $260 \mathrm{~nm}$. The ratio of A 260/280 was usually 2.0. RNA was stored at $-70^{\circ} \mathrm{C}$ until hybridization assays.

\section{Preparation of $\mathrm{CDNA}$ probe}

The mIGF-1 "cDNA insert (721 bp) was excised from the plasmid kindly provided by $\mathrm{G}$. I. Bell (Bell et al., 1986) by restriction enzyme digestion with EcoRI. Radioactive labelled mIGF-1 cDNA probe was prepared by multiprime DNA labelling system (Amersham) with ${ }^{32} \mathrm{P}-\mathrm{CTP}\left(11.1 \times 10^{4} \mathrm{GBq}\right.$, Amersham) to obtain a specific activity of $5-10 \times 10^{7} \mathrm{dpm} / \mu \mathrm{g}$ DNA template. The $\gamma$-actin cDNA (Ponte et al., 1983) was similarly labelled.

\section{Dot blot hybridization}

Denatured poly (A) RNA (5 $\mu \mathrm{g}$ ) was immobilized on prewetted Hybond $\mathrm{N}$ nylon membrane paper (Amersham, Japan) mounted in a microsample filtration vacuum minifold (Schleicher and Schue11, Keene, NH) and supported on NO. 470 paper (White and Bancroft, 1982). The paper was prehybridized, hybridized, washed, and autoradiographed with the modifications described previously (Thomas, 1980). Briefly, after prehybridization in $50 \%$ formamide, $1 \times$ Denhardt's solution $100 \mu \mathrm{g} / \mathrm{ml}$ denatured salmon sperma DNA, $5 \times$ SSPE and $1 \mu \mathrm{g} / 1$ SDS at $42^{\circ} \mathrm{C}$ overnight, hybridization was performed with ${ }^{32} \mathrm{P}$ labelled mIGF-1 cDNA probe for $48 \mathrm{~h}$. The hybridization signal was quantified by integrated densitometry of the autoradiographic images (Melmed et al., 1985). Filters were subsequently washed twice with $0.1 \%$ sodium dodecyl sulfate (SDS) and $0.2 \times$ sodium chloride-sodium citrate (SSC) at $95^{\circ} \mathrm{C}$ for $30 \mathrm{~min}$, and rehybridized with $\left[{ }^{32} \mathrm{P}\right] \gamma$-actin cDNA.

\section{RNA gel hybridization (Northern) analysis}

Fifteen micrograms of hepatic poly (A) RNA was denatured by incubation at $60^{\circ} \mathrm{C}$ and electrophoresed in a $1 \%$ agarose gel, as described previously (Yamashita and Melmed, 1986). After RNA transfer from the gel to nylon membrane paper, the paper was prehybridized and hybridized with $10^{7} \mathrm{cpm}\left[{ }^{32} \mathrm{P}\right]$ mIGF-IcDNA probe before exposure to X-ray film for autoradiography (Murphy et al., 1987).

\section{Statistical analysis}

All data are presented as the mean \pm SEM. Significance was assessed by nonpaired Student's $t$-test. 
Table 1. Circulating Thyroid Hormone Levels in Rats with Thyroid Dysfunction

\begin{tabular}{lcccc}
\hline \hline & Shams & Group 1 & $\begin{array}{c}\text { Group 2 } \\
\text { Thyroidectomized }\end{array}$ & Group 3 \\
& $(\mathrm{n}=10)$ & $\begin{array}{c}\text { (thyroidectomized) } \\
(\mathrm{T}=10)\end{array}$ & $\begin{array}{c}\left.\mathrm{T}_{4} \text { supplemented }\right) \\
(\mathrm{n}=5)\end{array}$ & $\begin{array}{c}\text { (hyperthyroid) } \\
(\mathrm{n}=10)\end{array}$ \\
\hline $\mathrm{T}_{3}(\mathrm{ng} / \mathrm{ml})$ & $98 \pm 6$ & $31 \pm 4^{*}$ & $100 \pm 2$ & $199 \pm 29^{* *}$ \\
$\mathrm{~T}_{4}(\mu \mathrm{g} / \mathrm{ml})$ & $4 \pm 0.2$ & $1.4 \pm 0.2^{*}$ & $4.2 \pm 1$ & $18 \pm 2^{* *}$ \\
\hline
\end{tabular}

Each value represents mean $\pm \mathrm{SEM} ; *$, ** $\mathrm{p}<0.001$ vs shams

\section{Results}

\section{Circulating thyroid hormone levels}

As depicted in Table 1, serum thyroid hormone levels in thyroidectomized rats were significantly lower than in euthyroid control animals. Five days after $\mathrm{T}_{4}$ re-

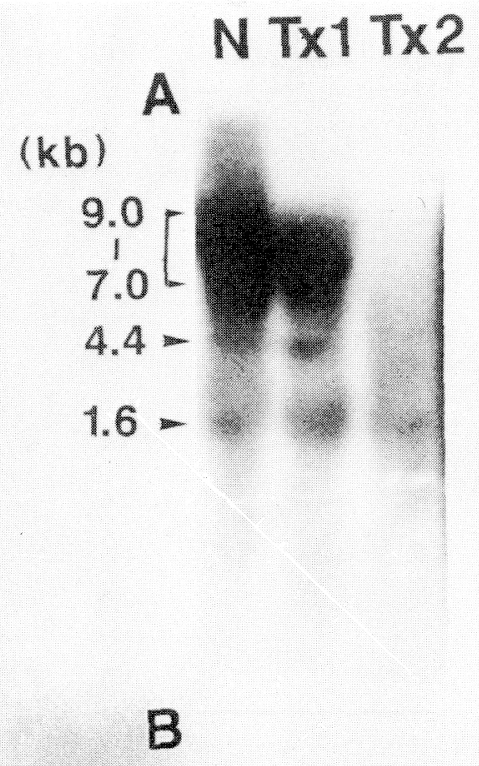

( $k b)$

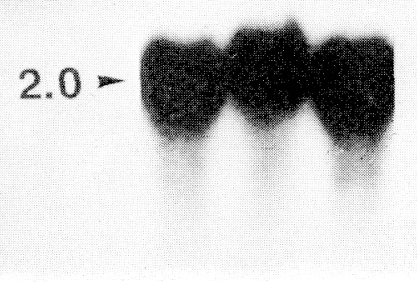

placement, serum $T_{3}$ and $T_{4}$ were restored to control levels. Two weeks after $T_{4}$ injection to normal rats, serum levels of $T_{3}$ and $T_{4}$ were significantly higher than those of control rats.

\section{Expression of hepatic IGF-1 mRNA}

Northern gel analysis of $15 \mu \mathrm{g}$ poly (A) RNA extracted from rat liver is shown in Fig. 1. Discrete bands of IGF-1 mRNA transcripts were apparent in normal rat liver. After thyroidectomy, the level of hepatic IGF-1 mRNA transcripts was decreased in a time dependent manner. All the IGF-1 mRNA species $(1.6 \mathrm{~Kb}, 4.4 \mathrm{~Kb}$ and $7-9.0 \mathrm{~Kb}$, respectively) were reduced

Fig. 1. Northern gel analysis. A: Poly (A) RNA $(15 \mu \mathrm{g})$ extracted from normal and thyroidectomized liver was electrophoresed in each lane for $3.5 \mathrm{~h}(100 \mathrm{~V}, 30 \mathrm{~mA})$ on $1.0 \%$ agarose in $6 \%$ formaldehyde. The gel was blotted on nylon membrane paper (Hybond $\mathrm{N}$, Amersham), hybridized with ( $\left.{ }^{32} \mathrm{P}\right)$-labelled mIGF-I cDNA, (s.a. $1 \times 10^{8} \mathrm{cpm} / \mu \mathrm{g}$ DNA), and autoradiographed. Standard size markers (Hind III digested $2 \mathrm{DNA}$ ) were electrophoresed in a parallel lane and the size of the hybridizing bands is indicated on the left. B: The same paper was reprobed with $\left({ }^{32} \mathrm{P}\right)$-labelled $\gamma$-actin cDNA. The hybridization signal (ca. $2.0 \mathrm{~Kb}$ ) was not altered by these treatments. $\mathrm{N}$ : normal rat liver. TX1: hypothyroid rat liver (2 weeks after thyroidectomy). TX2: hypothyroid rat liver (4 weeks after thyroidectomy). 


\section{N TX $\stackrel{\text { TX }}{\stackrel{+}{+}}$ T4}

Fig. 2. Representative autoradiograph of dot blot hybridization of hepatic poly (A) RNA. Triplicate blots (5 $\mu \mathrm{g}$ poly (A) RNA each) from each liver were immobilized and hybridized with $\left({ }^{32} \mathrm{P}\right)$-labelled mIGF-I cDNA as described in the text. $\mathrm{N}$ : Normal rat liver, TX: Hypothyroid rat liver, TX $+\mathrm{T}_{4}$ : TX with $\mathrm{T}_{4}$ replacement, $\mathrm{T}_{4}$ : Normal rat liver following $\mathrm{T}_{4}$ administration. to a similar degree in the liver after thyroidectomy. The $\gamma$-actin mRNA levels were not changed by this treatments.

\section{Regulation of hepatic IGF-1 mRNA}

When hepatic poly (A) RNA derived from hypothyroid rats was hybridized with the ${ }^{32}$ P-labelled IGF-I cDNA probe, the intensity of the IGF-1 mRNA transcripts was altered. Triplicate dots in a representative autoradiography are shown in Fig. 2. These suppressed mRNA levels were restored to euthyroid levels by thyroid hormone replacement. In contrast, hyperthyroid rats did not contain altered levels of hepatic IGF-1 mRNA as compared to euthyroid rats. The intensity of each dot was measured by optical densitometry (Fig. 3). The level of hepatic IGF-1 mRNA in $T X$ rats was significantly decreased compared to that of normal rats $(p<0.001)$. However, $\mathrm{T}_{4}$ administration in normal rats did not affect the level of hepatic IGF-1 mRNA. In contract, the $\gamma$-actin mRNA hybridization signal was not altered in hypothyroid or hyperthyroid rats.

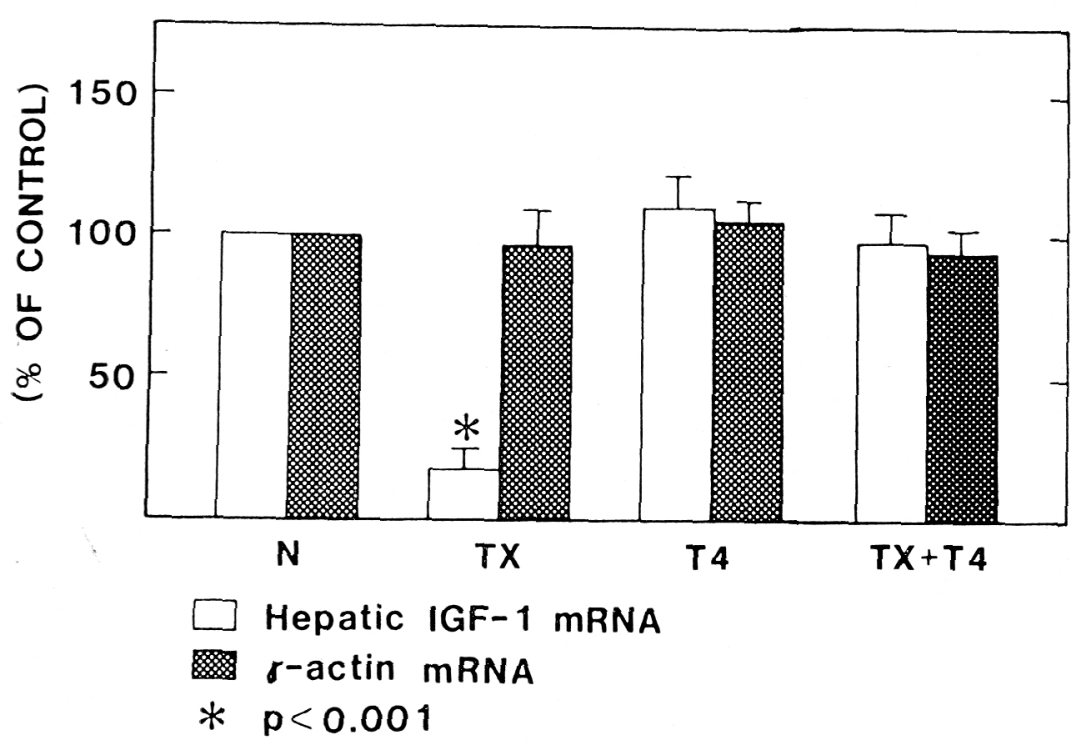

Fig. 3. Densitometric analysis of dot blot hybridization. Each bar represents the mean \pm SEM of triplicate dots. 


\section{Discussion}

The present findings demonstrate the effect of thyroidectomy and thyroid hormone replacement on the abundance of hepatic IGF-1 mRNA. Rat liver contains several mRNA transcripts $(1.6,4.4,7.0-9.0$ $\mathrm{Kb})$ which hybridize to a mouse IGF-1 cDNA probe. Signal intensities of all hybridizing IGF-1 mRNAs were lower in hepatic poly (A) RNA derived from thyroidectomized animals than in normal rats.

Previous studies have shown the distribution of hepatic IGF-1 mRNA (Murphy et al., 1987 ; Daughaday and Potwein, 1989) and the GH dependence of IGF-1 mRNA levels in rat liver (Hynes et al., 1987). Since serum GH levels were dramatically suppressed in hypothyroid rats (Matsuo et al., in press), our data demonstrate the same effect of thyroidectomy on hepatic IGF-1 mRNA. Furthermore, thyroid hormone replacement in thyroidectomized rats $(\mathrm{GH}: \quad 49 \pm 17 \mathrm{ng} / \mathrm{ml})$ restored circulating $\mathrm{GH}$ to normal euthyroid levels $(\mathrm{GH}: 190 \pm$ $31 \mathrm{ng} / \mathrm{ml}$ ), and also reversed the attenuation of hepatic IGF-1 mRNA in these animals. However, hyperthyroid rats did not demonstrate changes in hepatic IGF-1 mRNA in our study. This remains to be further investigated. A direct effect of $\mathrm{T}_{4}$ on the expression of hepatic IGF-1 mRNA transcription or stability cannot presently be excluded. Nevertheless, these observed changes are probably secondary to the induction of $\mathrm{GH}$ secretion by the exogenous $\mathrm{T}_{4}$ in thyroidectomized rats, although the tissue origins of circulating IGF-1 and intracellular mechanisms regulating IGF-1 synthesis are not clearly established. The strong correlations between hepatic IGF-1 content and circulating IGF-1 levels indicate the liver as a major source of IGF-1 in the circulation (Schwander et al., 1983). Furthermore, recent evidence indicates hepatic IGF-1 regulation at the mRNA level (Hynes et al., 1987; Lowe et al., 1988). The fluctuation in mRNA levels could reflect changes in the transcriptional rate or in mRNA stability. IGF-1 gene expression in both man (Ullrich et al., 1984) and rat (Shimatsu and Rotwein, 1987) appears to include the possibility of alternative RNA processing, although alternative processing seems unlikely based on the coordinate fall in different mRNA transcripts with hypothyroid liver. The induction of IGF-1 mRNA by estrogen was observed in the rat uterus (Murphy et al., 1987) and a relative increase in IGF-1m RNA in compensatory renal hypertrophy was also reported (Fagin and Melmed, 1987). Furthermore, in streptozotocin-diabetes rats, hepatic IGF1 mRNA was decreased (Goldstein et al., 1988). If a thyroid hormone responsive element resides within the IGF-1 gene, a direct action of thyroid hormone on IGF-1 gene expression may be speculated. However, the promoter regions of the IGF-1 gene have not been sufficiently delineated to permit speculation as to the likely site of distorted regulation in hypothyroid rats. Recently we have demonstrated the in vivo regulation of IGF-1 recepter by $\mathrm{T}_{3}$ in thyroidectomized rats (Matsuo et al., 1990). Taken together, thyroid hormone may play an important role in regulating IGF-1 action at the IGF-1 production site and/or at the IGF-1 targeting site..

\section{Acknowledgement}

We are grateful to Yumi Tanaka and Yumi Takahara for their secretarial assistance.

This work was supported by Uehara Memorial Foundation.

\section{References}

Bell, G. I., M. M. Stempien, N. M. Fong and L. B. Rall (1986). Sequences of liver cDNAs 
encoding two different mouse insulin-like growth factor I precursors. Nucleic, Acid. Res. 14, 7873-82.

Chomczynski, P. and N. Sacchi (1987). Singlestep method of RNA isolation by acid guanidium thiocyanate-phenol-chloroform extraction. Anal. Biochem. 162, 156-9.

Daughaday, W. H. and P. Potwein (1989). Insulin-like growth factors I and II peptide. messenger ribonucleic acid and gene structures, serum, and tissue concentrations. Endocrine Reviews 10, 68-91.

D'Ercole, A. J., A. D. Stiles and L. E. Underwood (1984). Tissue concentrations of somatomedin $\mathrm{C}$ : further evidence for multiple sites of synthesis and paracrine or autocrine mechanisms of action. Proc. Natl. Scad. Sci. $U S A, 81,935-9$.

Dobner. P. R., E. S. Kawasaki, L. Y. Yu and F. C. Bancroft (1981). Thyroid or glucocorticoid hormone induces pregrowth hormone mRNA and its probable nuclear precursor in rat pituitary cells. Proc. Natl. Acad. Sci. USA, 78, 2230-4.

Fagin, J. A., S. Pixley, S. Salanina, J. Ong and S. Melmed (1987). Insulin-like growth factor I gene expression in $\mathrm{GH}_{3}$ rat pituitary cells : Messenger ribonucleic acid content immunocytochemistry, and secretion. Endocrinology 120, 2037-43.

Fagin, J. A. and S. Melmed (1987). Relative increase in insulin-like growth factor I messenger ribonucleic acid levels in compensatory renal hypertrophy. Endocrinology 120, 71824.

Froesch, E. R., C. H. Schmidt, J. Schwander and J. Zapf (1985). Actions of insulin-like growth factors. Annu. Rev. Physiol. 47, 44367.

Goldstein, S., J. J. Stertich, K. R. Levan and L. S. Philips (1988). Nutrition and somatomedin XIX. Molecular regulation of insulinlike growth factor-I in streptozotocin-diabetes rats. Mol. Endcrinol. 2, 1093-100.

Hynes, M. A., J. J. Van Wyk, P. J. Brooks, A. J. D'Ercole, M. Jansen and P. K. Lund (1987). Growth hormone dependence of somatomedin-C/insulin-like growth factor-I and insulin-like growth factor-II messenger ribonucleic acids. Mol. Endocrinol. 1, 233-42.

Lowe, Jr. W. L., S. R. Lasky, D. Le Roith and Jr. C. T. Roberts (1988). Distribution and regulation of rat insulin-like growth factor
I messenger ribonucleic acids encoding alternative carboxyterminal E-Peptides: evidence for differential processing and regulation in liver. Mol. Endocrinol. 2, 528-35.

Matsuo, K., S. Yamashita, M. Niwa, S. Hayakawa, S. Nagataki and S. Melmed (1990). Thyroid hormone regulates rat pituitary insulinlike growth factor I (IGF-I) receptors. Endocrinology 126, 550-4.

Melmed, S., L. Neilson and S. Slanina (1985). Insulin suppresses rat growth hormone messenger ribonucleic acid in rat pituitary cells. Diabetes 34, 409-12.

Murphy, L. J., G. I. Bell and H. G. Friesen (1987). Tissue distribution of insulin-like growth factor I and II messenger ribonucleic acid in the adult rat. Endocrinology 120, 1279-81.

Murphy, L. G., L. C. Murphy and H. G. Friesen (1987). Estrogen induces insulin-like growth factor-I expression in the rat uterus. Mol. Endocrinol. 1, 445-50.

Ponte, P., P. Gunning, H. Blau and L. Kedes (1983). Human actin genes are single copy for $\alpha$-skeletal and $\alpha$-cardiac actin but multicopy for $\beta$-and $\gamma$-cytoskeletal genes: 3'untranslated regions are isotype specific but are conserved in evolution. Mol. Cell. Biol. 3, 1783-91.

Schwander, J. C., C. Hauri, J. Zapf and E. R. Froesch (1983). Synthesis and secretion of insulin-like growth factor-I and its binding protein by the perfused rat liver: dependence on growth hormone status. Endocrinologv 113, 297-305.

Shimatsu, A. and P. Rotwein (1987). Mosaic evolution of the insulin-like growth factors. Organization, sequence and expression of the rat insulin-like growth factor I gene. J. Biol. Chem. 262, 7894-900.

Thomas, P. S. (1980). Hybridization of denatured RNA and small DNA fragments transferred to nitrocellulose. Proc. Natl. Acad. Sci. USA 77, 5201-5.

Ullrich, A., C. H. Berman, T. J. Dull, A. Gray and J. M. Lee (1984). Isolation of the human insulin-like growth factor I gene using a single synthetic DNA probe. EMBO. J. 3, 361-4.

Van Wyk, J. J. The somatomedins : biological actions and physiological control mechanisms. In : Li CH (ed) Hormonal Proteins and Peptides. Academic Press, New York, PP81-125 
(1985).

Werner, D., Y. Chemla and M. Herzberg (1984).
Isolation of poly (A) + RNA by paper affinity chromatography. Anal. Biochem. 141, 32936.

White, B. A. and F. C. Bancroft (1982). Cytoplasmic dot hybridization: simple analysis of relative mRNA levels in multiple small cell or tissue samples. J. Biol. Chem. 257, 856972.

Yaffe, B. M. and H. H. Samuels (1984). Hormonal regulation of the growth hormone gene.
J. Biol. Chem. 259, 6284-91.

Yamashita, S., S. Morita, K. Ashizawa, S. Harakawa, M. Izumi and S. Nagataki (1989). Molecular mechanism of pituitary cell proliferation by thyroid hormone. The 4th Asia and Oceania Thyroid Association Meeting (Seoul), Abstract P13.

Yamashita, S. and S. Melmed (1986). Effects of insulin on rat anterior pituitary cells : inhibition of growth hormone secretion and mRNA levels. Diabetes 35, 440-7. 